\title{
Case Report: A giant myopericytoma involving the occipital region of the scalp - a rare entity [version 1; peer review: 3
}

\section{approved]}

\author{
Sunil Munakomi (i), Pramod Chaudhary \\ Department of Neurosurgery, College of Medical Sciences, Chitwan, Nepal
}

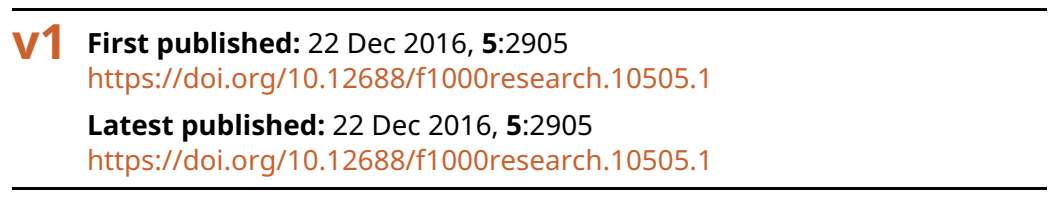

\section{Abstract}

Herein we report a rare case of a giant myopericytoma presenting in a 16-year-old girl as a slowly progressive swelling involving the scalp in the occipital region. It was managed by complete excision.

Histological examination of the lesion revealed spindle-shaped cells forming characteristic rosettes around the blood vessels, and positive staining with smooth muscle actin.

\section{Keywords}

myopericytoma, subcutaneous lesion, scalp

\section{Open Peer Review \\ Approval Status $\checkmark \checkmark$ \\ 12 \\ 23 \\ version 1 \\ 22 Dec 2016

$\checkmark$
view

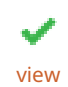 \\ 1. Ravi Dadlani, Apollo Speciality Hospital, Nellore, India \\ 2. Sanela Zukić ID , University Clinical Center \\ Tuzla, Tuzla, Bosnia and Herzegovina \\ 3. Umit Eroglu, Ankara University, Ankara, \\ Turkey}

Any reports and responses or comments on the article can be found at the end of the article.

Corresponding author: Sunil Munakomi (sunilmunakomi@gmail.com)

Competing interests: No competing interests were disclosed.

Grant information: The author(s) declared that no grants were involved in supporting this work.

Copyright: @ 2016 Munakomi S and Chaudhary P. This is an open access article distributed under the terms of the Creative Commons Attribution License, which permits unrestricted use, distribution, and reproduction in any medium, provided the original work is properly cited. The author(s) is/are employees of the US Government and therefore domestic copyright protection in USA does not apply to this work. The work may be protected under the copyright laws of other jurisdictions when used in those jurisdictions.

How to cite this article: Munakomi S and Chaudhary P. Case Report: A giant myopericytoma involving the occipital region of the scalp - a rare entity [version 1; peer review: 3 approved] F1000Research 2016, 5:2905 https://doi.org/10.12688/f1000research.10505.1 First published: 22 Dec 2016, 5:2905 https://doi.org/10.12688/f1000research.10505.1 


\section{Introduction}

Myopericytoma is a rare entity. It mostly involves the skin and subcutaneous tissue of the distal extremities, torso, head and neck regions $^{1-3}$. Rarely does it involve the visceral sites ${ }^{4,5}$. The spindle shaped cells of a myopericytoma show characteristic perivascular rosettes ${ }^{6,7}$. Though mostly benign, rare cases of its malignant counterpart have been described ${ }^{8}$. We report a case of a giant myopericytoma involving the occipital region of the scalp of a young female, with good post-operative outcome following its complete excision. We believe this is the first case report of a giant myopericytoma involving this region.

\section{Case report}

A 16-year-old female from Butwal, Nepal presented to our outpatient clinic with a chief complaint of slow progressive swelling in the occipital region of the scalp, which she had been experiencing for the last 2 years. There was no history of trauma, pain, tinnitus, dizziness or discharge associated with the lesion, and no significant previous medical or surgical illnesses had been reported. Local examination revealed a soft to firm subcutaneous lesion measuring $9 \times 8 \mathrm{~cm}^{2}$, with no bruit within the lesion and normal overlying skin. There was no transmitted pulsation or cough impulse, and there were no palpable bony defects felt around the margins of the lesion. Lower cranial nerve examination was normal and cerebellar signs were negative. CT findings showed a homogeneously enhanced subcutaneous lesion (Figure 1), but with no intracranial extension (Figure 2).

After thorough counselling and consent, the patient was booked in for excision of the lesion. Adequate blood for transfusion was supplied because of the vascularity of the scalp and the giant size

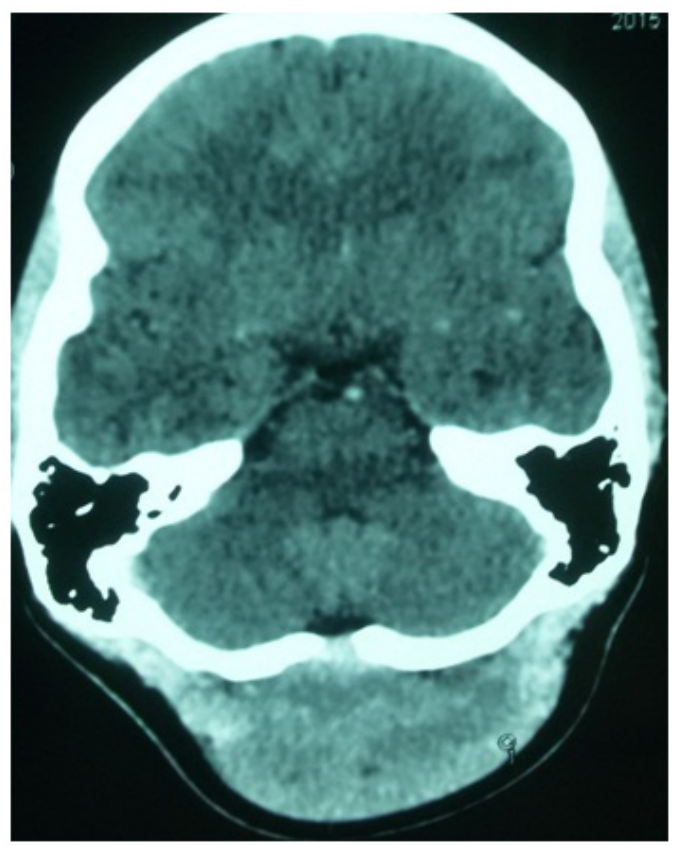

Figure 1. CT image showing homogeneously enhanced lesion in the scalp of occipital region. of the lesion. A midline incision was given, with the patient in the prone position. The edges of the lesion were vascular, with major pedicles from bilateral occipital arteries. Complete excision was undertaken (Figure 3). Intra-operatively, the patient was transfused two pints of blood. Post-operative recovery was uneventful land she was discharged on the third day. Histological examination of the lesion revealed presence of spindle-shaped cells, forming characteristic rosettes around the blood vessels. Positive staining for smooth muscle actin (SMA) was highly suggestive for myopericytoma (Figure 4), and the lack of mitotic cells or tissue necrosis confirmed

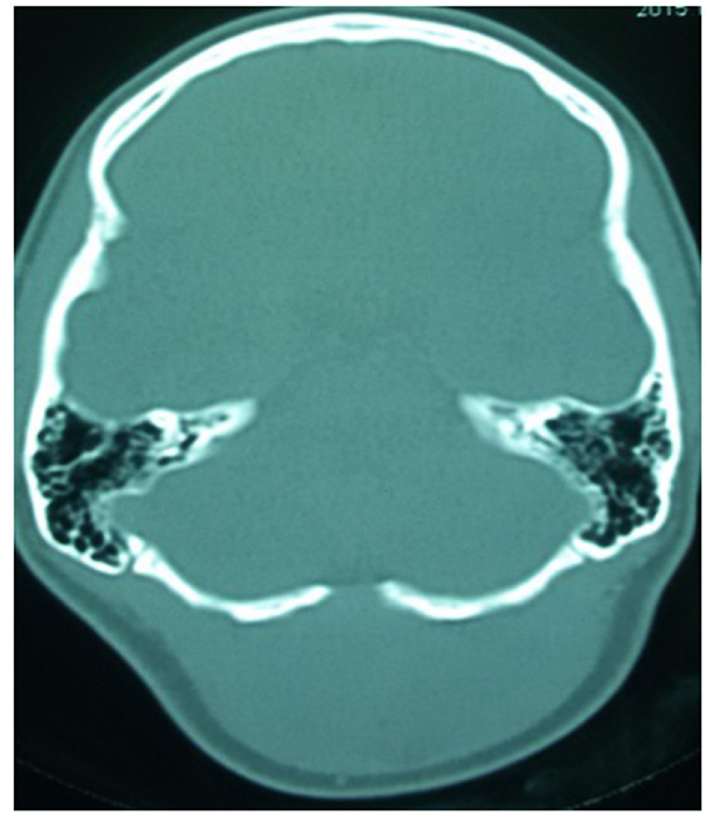

Figure 2. CT bone window showing a minimal osseous gap in the midline but no intracranial extension of the lesion.

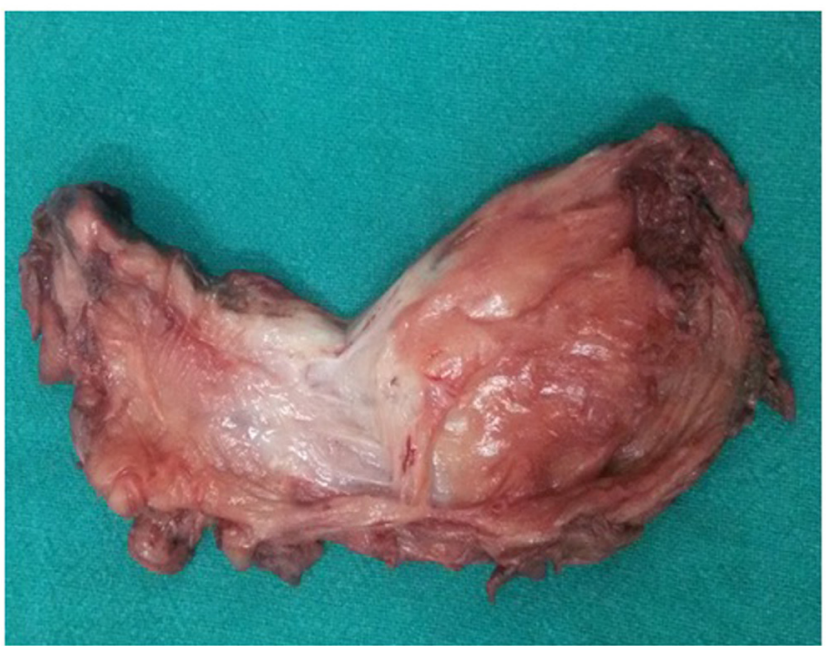

Figure 3. Excised specimen showing the giant lesion, of firm consistency and with no visible necrotic areas. 


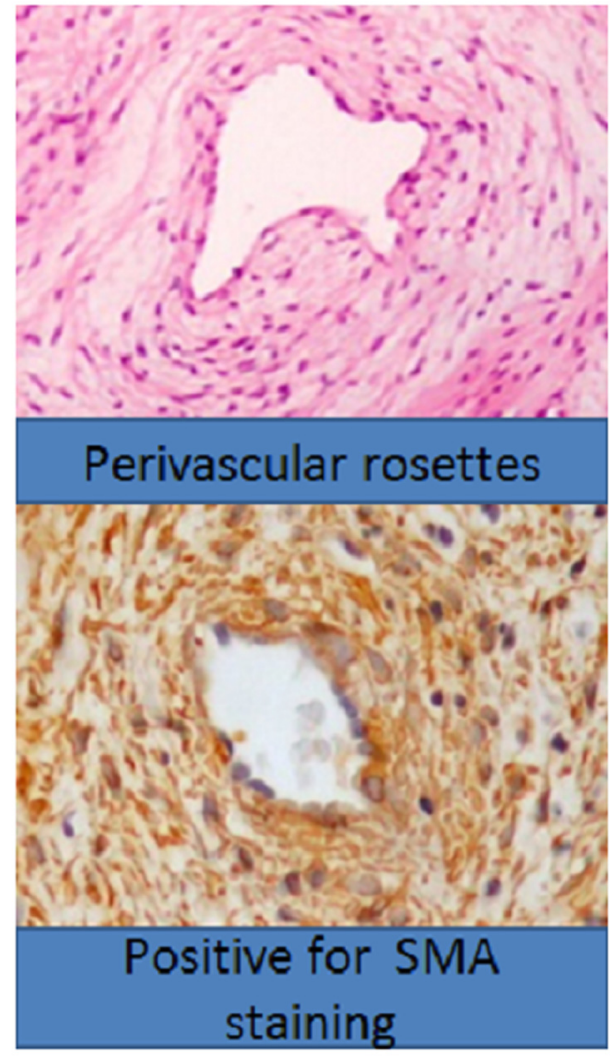

Figure 4. Photomicrograph of tissue taken from the lesion excised from the patient, showing characteristic spindle cells forming perivascular rosettes and staining with smooth muscle actin (SMA).

its benign nature. Patient follow-up took place 2 weeks later, with no symptoms and a well healed wound. She was advised to come for periodic follow-ups every month.

\section{Discussion}

Myopericytoma has been described as being a type of perivascular tumor in the latest edition of World Health Organization classification of tumors of soft tissue and bone ${ }^{6}$. Histologically it is characterized by spindle cells forming perivascular rosettes and staining positive for SMA and negative for Desmin, Bcl2 and CD34. Though usually the size of a myopericytoma is less than $2 \mathrm{~cm}$ in superficial soft tissue, larger tumor size has been reported in the visceral locations ${ }^{10,11}$. Some cases of the malignant form showing invasion, mitotic figures and necrosis have been described $^{6}$. These malignant forms also show a high Ki-67 proliferative index, contrary to benign forms with low Ki-67 index ${ }^{12}$.

Prior to diagnosing the myopericytoma, initially the major differential diagnosis was of a giant diffuse lipoma. Other differential diagnoses included other mesenchymal lesions, like desmin positive angioleiomyomas, glomus tumors in which epitheloid cells form rosettes, and solitary fibrous tumors, which do not form visible perivascular rosettes ${ }^{13}$. These can be differentiated on the basis of their characteristic immunohistological reactivity patterns, such as positive staining with SMA and often also with h-Caldesmon .

Recurrence of the tumor can occur, even in benign cases, so complete excision should be the goal ${ }^{13}$. Following complete excision, patients should return for periodic follow-ups despite the benign nature of the tumor.

\section{Conclusion}

Though a rarity, myopericytoma should be ruled out prior to surgical management of subcutaneous lesions, because sometimes the high vascular nature of the lesion may impose difficulties during its excision and pose a risk to the patients' life if adequate arrangements for blood transfusions have not been made.

\section{Consent}

Written informed consent for publication of the patient's details and their images was obtained from the guardian of the patient.

\section{Author contributions}

Both authors contributed equally to the acquisition of data, literature review and preparation of the manuscript.

\section{Competing interests}

No competing interests were disclosed.

\section{Grant information}

The author(s) declared that no grants were involved in supporting this work.
1. Calonje E, Fletcher CD: Vascular Tumors. Philadelphia: Churchill Livingstone, Elsevier; 2013.

2. Díaz-Flores L, Gutiérrez R, García MP, et al:: Ultrastructure of myopericytoma: a continuum of transitional phenotypes of myopericytes. Ultrastruct Pathol. 2012; 36(3): 189-194.

PubMed Abstract | Publisher Full Text

3. Mentzel T, Dei Tos AP, Sapi Z, et al.: Myopericytoma of skin and soft tissues: clinicopathologic and immunohistochemical study of 54 cases. Am J Surg Pathol. 2006; 30(1): 104-113.

PubMed Abstract

4. Akbulut S, Berk D, Demir MG, et al:: Myopericytoma of the tongue: a case report. Acta Medica (Hradec Kralove). 2013; 56(3): 124-125. PubMed Abstract | Publisher Full Text

5. Numata I, Nakagawa S, Hasegawa S, et al.: A myopericytoma of the nose. Acta 
Derm Venereol. 2010; 90(2): 192-193.

PubMed Abstract

6. Fletcher CD, Bridge JA, Hogendoom PC, et al: World Health Organization Classification of Tumours of Soft Tissue and Bone. Lyon: IARC Press; 2013. Reference Source

7. Fisher C: Unusual myoid, perivascular, and postradiation lesions, with emphasis on atypical vascular lesion, postradiation cutaneous angiosarcoma, myoepithelial tumors, myopericytoma, and perivascular epithelioid cell tumor. Semin Diagn Pathol. 2013; 30(1): 73-84

PubMed Abstract | Publisher Full Text

8. McMenamin ME, Fletcher CD: Malignant myopericytoma: expanding the spectrum of tumours with myopericytic differentiation. Histopathology. 2002; 41(5): 450-460.

PubMed Abstract | Publisher Full Text

9. Dray MS, McCarthy SW, Palmer AA, et al:: Myopericytoma: a unifying term for a spectrum of tumours that show overlapping features with myofibroma. A review of 14 cases. J Clin Pathol. 2006; 59(1): 67-73.

PubMed Abstract | Publisher Full Text | Free Full Text

10. Lau SK, Klein R, Jiang Z, et al.: Myopericytoma of the kidney. Hum Pathol. 2010, 41(10): 1500-1504

PubMed Abstract | Publisher Full Text

11. Dhingra S, Ayala A, Chai $\mathrm{H}$, et al.: Renal myopericytoma: case report and review of literature. Arch Pathol Lab Med. 2012; 136(5): 563-566.

PubMed Abstract | Publisher Full Text

12. Terada T: Minute myopericytoma of the neck: a case report with literature review and differential diagnosis. Pathol Oncol Res. 2010; 16(4):

613-616.

PubMed Abstract | Publisher Full Text

13. Aung PP, Goldberg LJ, Mahalingam M, et al:: Cutaneous Myopericytoma: A Report of 3 Cases and Review of the Literature. Dermatopathology (Basel). 2015; 2(1): 9-14.

PubMed Abstract | Publisher Full Text | Free Full Text 


\section{Open Peer Review}

\section{Current Peer Review Status:}

\section{Version 1}

Reviewer Report 08 February 2017

https://doi.org/10.5256/f1000research.11323.r19615

(c) 2017 Eroglu U. This is an open access peer review report distributed under the terms of the Creative Commons Attribution License, which permits unrestricted use, distribution, and reproduction in any medium, provided the original work is properly cited.

\section{Umit Eroglu \\ Department of Neurosurgery, School of Medicine, Ibni Sina Hospital, Ankara University, Ankara, Turkey \\ İt is a well written article and contains novel knowledge. \\ It is an original article but provides minimal sufficient details for practitioners. \\ It includes a background of the case's history and progression and provides details of any physical examination and diagnostic tests, treatment given and outcomes. \\ It includes a discussion of the importance of the findings that also describes their relevance to future understanding of disease processes, diagnosis or treatment. \\ Competing Interests: No competing interests were disclosed. \\ I confirm that I have read this submission and believe that I have an appropriate level of expertise to confirm that it is of an acceptable scientific standard.}

Reviewer Report 07 February 2017

\section{https://doi.org/10.5256/f1000research.11323.r19917}

(C) 2017 Zukić S. This is an open access peer review report distributed under the terms of the Creative Commons Attribution License, which permits unrestricted use, distribution, and reproduction in any medium, provided the original work is properly cited.

\section{Sanela Zukić}

Department of Neurology, University Clinical Center Tuzla, Tuzla, Bosnia and Herzegovina

This case is very interesting, and describes the rare entity which will serve in the medical practice.

The title is appropriate for the content of the article and the abstract represent a suitable 
summary of the work.

The design, methods and analysis of the results from the study been explained and are they appropriate for the topic being studied.

Also, the conclusions are sensible, balanced and justified on the basis of the results of the study.

Competing Interests: No competing interests were disclosed.

\section{I confirm that I have read this submission and believe that I have an appropriate level of expertise to confirm that it is of an acceptable scientific standard.}

Reviewer Report 23 January 2017

\section{https://doi.org/10.5256/f1000research.11323.r19555}

(C) 2017 Dadlani R. This is an open access peer review report distributed under the terms of the Creative Commons Attribution License, which permits unrestricted use, distribution, and reproduction in any medium, provided the original work is properly cited.

\section{Ravi Dadlani}

Department of Neurosurgery, Apollo Speciality Hospital, Nellore, Andhra Pradesh, India

I congratulate Dr Munakomi et al for an interesting article.

The following are my comments:

The article is well written and highlights a rare pathological entity which may thought of in the differential diagnosis of large scalp lesions.

1. A clinical photograph outlining the lesion would be interesting.

2. There are no MRI images. Any large scalp tumor should have a pre-op MRI. If MRI images are available kindly upload those.

3. English language editing is recommended e.g. instead of using the word 'pint' the word 'unit of blood' seems more appropriate.

4. There is no discussion on the radiological characteristics of the tumor and its differential diagnosis.

5. It would be interesting to have a tabulated review of literature of myopericytomas of the scalp.

6. I would also recommend the authors provide a table of differential diagnosis of various pathologies and their immunohistochemical characterizations.

7. Although the take home message appears to be a high clinical suspicion in order to prevent excess blood loss intra-operatively, the authors do not specifically mention any particular 
measures, if any, they took to minimize bleeding intra-operatively.

8. A two week follow up is too short for any tumor and some discussion on how frequent (\%) is the recurrence after complete excision and what is the treatment strategy for recurrences.

Final Verdict: Paper may be accepted for indexing with the relevant changes.

Competing Interests: No competing interests were disclosed.

I confirm that I have read this submission and believe that I have an appropriate level of expertise to confirm that it is of an acceptable scientific standard.

The benefits of publishing with F1000Research:

- Your article is published within days, with no editorial bias

- You can publish traditional articles, null/negative results, case reports, data notes and more

- The peer review process is transparent and collaborative

- Your article is indexed in PubMed after passing peer review

- Dedicated customer support at every stage

For pre-submission enquiries, contact research@f1000.com 